Al-Uqud: Journal of Islamic Economics E-ISSN 2548-3544, P-ISSN 2549-0850 Accredited No. 28/E/KPT/2019
Volume 4 Issue 1, January 2020

DOI:10.26740/al-uqud.v4n1.p104-114

Page 104-114

\title{
Source of Funds and Islamic Insurance Growth: Investment Returns as a Mediation
}

\author{
Dhidhin Noer Ady Rahmanto ${ }^{1 *}$, Muhammad Iqbal Fasa, ${ }^{2}$ Khoirul Rijal $^{3}$ \\ ${ }^{1}$ Department of Islamic Banking, Faculty of Islamic Religion, Universitas Alma Ata \\ Yogyakarta. Jalan Brawijaya No.99, Bantul, Yogyakarta 55183, Indonesia. \\ ${ }^{2}$ Department of Islamic Banking, Faculty of Islamic Economics and Business, Universitas \\ Islam Negeri Raden Intan Lampung. Jalan Letnan Kolonel H Jl. Endro Suratmin, Lampung \\ 35131, Indonesia \\ ${ }^{3}$ Department of Finance, Kulliyyah of Economics and Management Sciences, International \\ Islamic University Malaysia. Jalan Gombak, 53100 Kuala Lumpur, Malaysia
}

\begin{abstract}
Sustainable growth must be maintained by maintaining an increase in investment returns, with the source of funds as a stimulant. The population of this study was all Islamic life insurance companies in Indonesia. The study used path analysis mediation with regression or two layers OLS (Ordinary Least Squares) and followed by Sobel test. The result showed that investment returns can mediate participant funds in influencing the growth of Islamic life insurance companies. Meanwhile, investment returns did not mediate the influence of company funds in influencing the growth of Islamic life insurance companies.
\end{abstract}

Keywords: Islamic life insurance; Company growth; Path analysis

Paper type: Research paper

*Corresponding author: dna.rahmanto@uaa.ac.id

Received: April 26, 2019; Accepted: January 13, 2020; Published: January 20, 2020

Cite this document: Rahmanto, D., N., A., Fasa, M., I. \& Rijal., K. (2020). Source of Funds and Islamic Insurance Growth: Investment Returns as a Mediation. Al-Uqud: Journal of Islamic Economics, 4(1), 104-114. doi: http://dx.doi.org/10.26740/aluqud.v4n1.p104-114

Copyright () 2020, Al-Uqud: Journal of Islamic Economics http://journal.unesa.ac.id/index.php/jie 


\begin{abstract}
Abstrak: Pertumbuhan yang berkelanjutan harus terus terjaga dengan menjaga kenaikan hasil investasi, yang dimana sumber dana sebagai pendorongnya. Populasi penelitian keseluruhan perusahaan asuransi jiwa syariah di Indonesia. Teknik analisis menggunakan mediasi analisis jalur dengan regression yang sering disebut OLS (Ordinary Least Squares) dua layer atau dua model dan dilanjutkan uji sobel. Hasil penelitian menunjukkan bahwa hasil investasi dapat memediasi dana peserta dalam mempengaruhi pertumbuhan perusahaan asuransi jiwa syariah. Sementara, hasil investasi tidak dapat memediasi pengaruh dana perusahaan dalam mempengaruhi pertumbuhan perusahaan asuransi jiwa syariah.
\end{abstract}

Kata kunci: Asuransi jiwa syariah; Pertumbuhan perusahaan; Analisis jalur

\title{
INTRODUCTION
}

Islamic Insurance Growth in Indonesia continues to increase. The Financial Services Authority (OJK) has been recorded as of May 2016 Islamic IKNB assets contributed 4.66 percent of total sharia financial assets. It is contributed from Islamic insurance company assets of IDR 29.83 trillion. This is also observed by the growth in Islamic life insurance and Islamic general insurance premium, which grew by $26.1 \%$ and $28.8 \%$ respectively. This growth is quite good compared to conventional insurance premium growth which is only $12 \%-18 \%$. A good premium growth must be followed by good investment results to increase optimal company growth. In general, the company has a goal in its sustainability for profitability (profitability), growth (growth), survival (survival). Survival without growth means the company is hopeless. Meanwhile, profitability disregarding survival is very risky. Further, growth without profitability is impossible.

The company's capital position is one of the investment growth determinants that can be maximized to increase investment business returns. Strong capital also enhances the company's ability to survive in the face of financial pressures and provides large financials (Almajali et al, 2012). The Financial Services Authority (OJK) explained the amount of sharia life insurance investment also increased by $3.7 \%$ compared to the previous month to Rp17.45 trillion from Rp18.13 trillion in July 2015 (OJK, 2015). Until August 2015, the results of Islamic life insurance investments still lost IDR 848 billion. This value was escalated from investment losses in July 2015 which reached IDR 364 billion.

Insurance is a financial institution that is always on the government attention (Muye et al, 2015). It is since the insurance business is an institution that is very vulnerable to risk. Judging from the risk that insurance has so much, then the growth of insurance is taken for consideration. Even in developing countries like Malaysia, insurance plays an important role in the development of economic growth (Hassan et al, 2014). Previous researches already proved as the reason to conduct in-depth studies about insurance, particularly Islamic insurance. Hence, researches to support the development of insurance business are needed.

Several studies have been conducted about Islamic and Conventional insurance concept. The fundamental difference concept between Islamic and Conventional insurance is the existence of tabarru' funds in Islamic Insurance 
(Nasution et al, 2019). Studies found that although Takaful business growth fast and healthy, it has a low market share and poor financial performance, though this is supported by a very positive market sentiment about Takaful insurance in Pakistan (Hanif et al, 2014). However, Islamic insurance show greater resilience than conventional ones during a crisis (Akhter et al, 2017).

The development of Islamic insurance led to significant growth result, a lot of literatures had been discussed the growth of the company but only few specifically examine the growth of the Islamic life insurance industry. Muthmainah, (2016) explained that Islamic life insurance investment returns as the main support of growth so that Islamic insurance must be better and more careful to invest. Nurbaya et al, (2019) stated that investment funds and total assets had a positive correlation in raising the prospects of the company, positive results were shown from all selected private life insurance companies. On the other hand, the investment portfolio of insurance companies must also be considered which is affected by quantity or volume (Mao et al, 2013). But Najjar et al, (2011) mentioned that profitability and revenue growth are not statistically significant, providing a loophole to examine whether the source of capital will affect growth through investment returns obtained by Islamic life insurance for further study. This makes the study interesting to be investigated as well as what steps are taken in maintaining growth. Then, this research examined how big the role of company funds and premium funds of participants in increasing the growth of insurance companies through investment returns as an intervening variable or mediator.

\section{RESEARCH METHODS}

This study aimed to analyze the impact of source of funds to the growth of Islamic life insurance. The population in this study was Islamic life insurance companies in Indonesia. While the sampling technique used in this study was purposive sampling. The data was the company's annual reports for the period 2014-2016 which have been registered in the Financial Services Authority (OJK) publication.

The analysis technique used mediation path analysis with regression or two layers OLS (Ordinary Least Squares) that combined into one unit. This method previously was discussed by (Baron et al, 1986; Judd et al, 1981; and James et al, 1984). This method was also used by (Frazier et al, 2004). Mediation techniques according to Preacher et al, (2004) can also use the Sobel test as an additional reinforcement of results, as well as for indirect mediation Preacher et al (2008). It is justified by (Bolin, 2014). The regression model used in this study is as follows:

Layer I

$\mathrm{Y}_{1}=\beta_{1} \mathrm{Y}_{1} \mathrm{X}_{1}+\beta_{2} \mathrm{Y}_{1} \mathrm{X}_{2}+\varepsilon_{1}$

Layer II

$\mathrm{Y}_{2}=\beta_{1} \mathrm{Y}_{2} \mathrm{X}_{1}+\beta_{2} \mathrm{Y}_{2} \mathrm{Y}_{1}+\beta_{3} \mathrm{Y}_{2} \mathrm{X}_{2}+\varepsilon_{1}$ 


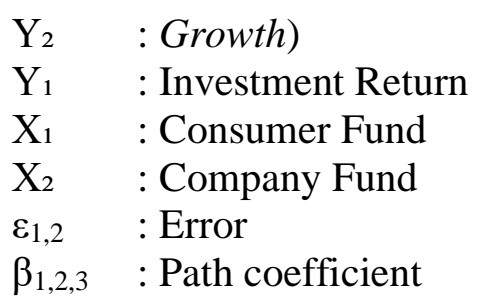

Furthermore, to ensure the sample used was BLUE (Best, Linear, Unbias dan Estimate), the data was tested using the classic assumption test. The classical assumption test was carried out to ensure that autocorrelation, multicollinearity, and heteroscedasticity were not found in this study or the data generated were normally distributed. The classic assumptions of regression fulfilled when those were not found.

\section{RESULTS AND DISCUSSION Normality Test}

Normality test aims to test whether in a regression, dependent variable, independent variable or both have normal distribution. This research used normality test with one-sample Kolmogorov-Smirnov. It meets the assumption of normality if the significance value is greater than the alpha value of 0.05 . The results of the normality test showed insignificant results. The value of Kolmogorov-Smirnov was 0.146 and the significance was 0.064 . Based on these results it can be concluded that the data were normally distributed.

\section{Multicollinearity Test}

Multicollinearity test is an assumption used to see whether there is a linear relationship between independent variables. If there is a relationship between independent variables in one regression it can be called multicollinearity. A good regression model is that there is no correlation between independent variables. The multicollinearity test output showed the tolerance value of all variables was greater than 0.10 and the VIF value did not exceed the value of 10 . Thus, it can be concluded that there was no multicollinearity

\section{Heteroscedasticity Test}

The heteroscedasticity test aims to find out whether there is an inequality of variance from the residuals. One way to detect the presence or absence of heteroscedasticity is test the glacier by regress the absolute residual value of the exogenous variables. The result showed there was no indication of heteroscedasticity since the significance value was above 0.05 .

\section{Autocorrellation Test}

The autocorrelation test is used to find out whether there is a correlation between the error of the intruder in the $t$ period and the previous period $(t-1)$. The output showed that the data did not have a correlation, because the run test value generated from the SPSS was 0.055, larger than the significance level of 0.05 . 
Based on the multiple linear regression tests at Layer 1, the SPSS output table is presented in table 1

Table 1. Multiple Linear Regression Test Results (Layer I)

\begin{tabular}{lrrr}
\hline \multirow{2}{*}{\multicolumn{1}{c}{ Var }} & \multicolumn{3}{c}{ Partial } \\
\cline { 2 - 4 } & \multicolumn{1}{c}{ T } & Sig & \multicolumn{1}{c}{ B } \\
\hline Constant & 0,117 & 0,907 & 1,092 \\
Customer Fund & 4,59 & 0,000 & 0,371 \\
Company Fund & 0,595 & 0,556 & 0,09 \\
\hline
\end{tabular}

\begin{tabular}{cccc}
\hline $\mathbf{R}$ & $\begin{array}{c}\text { Adjusted } \\
\text { Square }\end{array}$ & R Square & Sig. \\
\hline & & & \\
0,445 & 0,409 & 12,412 &, $000^{\mathrm{b}}$
\end{tabular}

Source : processed data

Further, the result of multiple linear regression tests at Layer II, the SPSS output table is presented in table 2

Table 2. Multiple Linear Regression Test Results (Layer II)

\begin{tabular}{|c|c|c|c|c|c|c|c|}
\hline \multirow{2}{*}{ Var } & \multicolumn{3}{|c|}{ Partial } & \multirow{2}{*}{$\begin{array}{c}\mathbf{R} \\
\text { Square } \\
\end{array}$} & \multirow{2}{*}{$\begin{array}{l}\text { Adjusted } \\
\text { R Square } \\
\end{array}$} & \multirow{2}{*}{$\mathbf{F}$} & \multirow{2}{*}{ Sig. } \\
\hline & $\mathbf{T}$ & Sig & B & & & & \\
\hline Constant &,- 028 & 978 &,- 001 & \multirow{4}{*}{0,923} & \multirow{4}{*}{0,915} & \multirow{4}{*}{119,035} & \multirow{4}{*}{, $000^{\mathrm{b}}$} \\
\hline Customer Fund & 1,747 & ,091 & 8,791 & & & & \\
\hline Company Fund & 16,800 &, 000 & $\begin{array}{r}, 0001 \\
56\end{array}$ & & & & \\
\hline Invest Returns & 3,512 & ,001 & 3,850 & & & & \\
\hline
\end{tabular}

Source : processed data

\section{Measurement of Mediation Variable}

The result of mediation variable showed in Figure 1

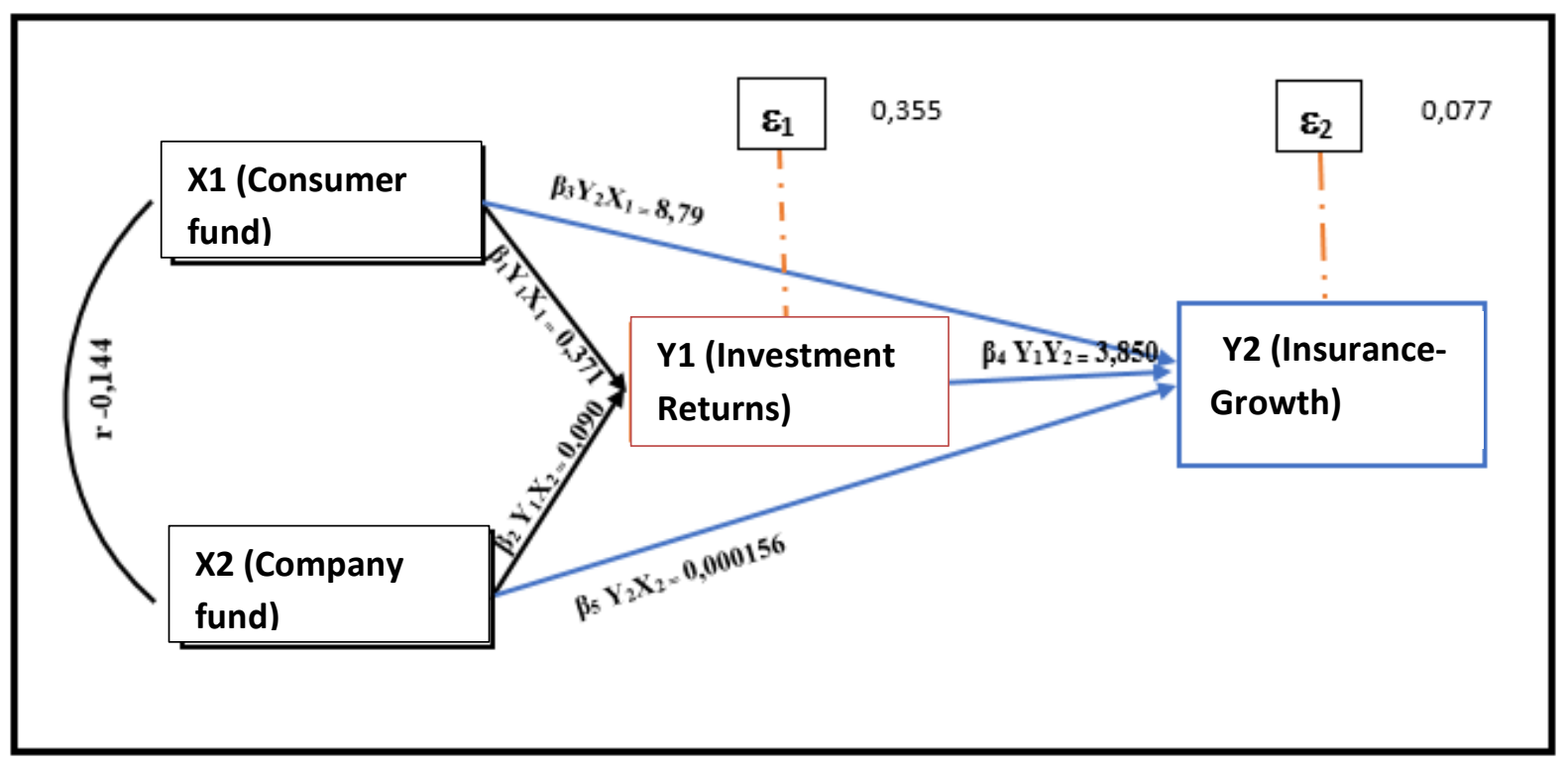

Figure 1. Path Diagram Model 
Figure 1 showed the coefficient value of consumer fund to corporate growth directly was 8.791, while indirectly was 1.428 . Hence, based on the coefficient value it can be said that the direct effect of consumer fund to corporate growth was better than its indirect effect. On the other hand, the coefficient value of corporate fund to corporate growth directly was 0,000156 , while indirectly was 0.3465 . Thus, the indirect effect of corporate funds was better than its direct effect.

\section{Uji Sobel Test.}

Sobel Test is a significance mediation coefficient test with the criteria that $\mathrm{t}$ mediation coefficient $>\mathrm{t}$ Sobel then the intervening variable is able to mediate exogenous variables with endogenous variables. Sobel test can also be known by comparing the results of the probability value with alpha 0.05 .

Table 3. Sobel Output Results Test of Consumer Fund on the growth of Islamic life insurance companies through investment returns

\begin{tabular}{llll}
\hline & Test Statistic & Std. Error & P-Value \\
\hline Sobel test & 4.58024691 & 0,31185 & 0,00000464 \\
Aroian test & 4.58024691 & 0,31185 & 0,00000464 \\
Goodman test & 4.58024691 & 0,31185 & 0,00000464 \\
\hline
\end{tabular}

Table 4. Sobel test Online result of Company Fund on the growth of Islamic life insurance companies through investment returns

\begin{tabular}{llll}
\hline & Test Statistic & Std. Error & P-Value \\
\hline Sobel test & 0,59602649 & 0,58135 & 0,55115753 \\
Aroian test & 0,59602649 & 0,58135 & 0,55115753 \\
Goodman test & 0,59602649 & 0,58135 & 0,55115753 \\
\hline
\end{tabular}

Based on the results of the Sobel test analysis, the impact of consumer funds to company growth mediated by investment returns was acceptable. Thus, the investment returns were able to mediate. In a significant level of 0.05 it can be seen that the probability value obtained is equal to $0,000<0.05$. Meanwhile, the impact of company funds to company growth mediated by investment returns had an output of the probability at 0.5511 , that higher than 0.05 . It can be concluded that investment returns are not able to mediate the influence of company funds on growth.

\section{Impact of Consumer Fund to Company Growth through Investment Result}

In funding, consumer fund is a source of fund that has a higher risk than company funds. The lesser the return of consumer fund, compare to the cost, the higher the risk borne by the company. While, the consumer funds generate profitable income, the risks can be covered so as to help the company's growth.

Consumer funds are the main driving force for the insurance company. Increasing consumer fund means increasing investment volume and company growth. However, increasing participant funds will be followed by increasing risks borne. A definite risk is the emergence of sudden claims in large volumes. In principle, Islamic insurance has a difference with insurance in general (conventional) even in competition and efficiency when carrying out its activities 
(Alshammari et al, 2018). Islamic insurance uses the risk sharing principle that the risk becomes a joint responsibility in the tabarru fund. Nevertheless, it does not affect the claim, because the claim is something that can at any time reduce the stability of the company (Nektarios, 2010). If claims always increase beyond the premium funds themselves, so the company's growth will be disrupted. This research is in line with research of Muthmainah (2016) stated that the growth of assets can affect the growth of Islamic insurance profitability.

\section{Impact of Company Fund to Company Growth through Investment Result}

Company funds will produce a large investment return if allocated to the investment due to only a small amount of inherent risk (Puspitasari, 2015). This will be able to help the company grow quickly if it has a large enough company funds. However, on the other hand the company needs liquid funds for the company's operations. The financial manager must be able to choose which sources of funds should be used for operational operations. Tabarru funds, taken from consumer funds, for the smooth operation of the company but the funds will still be invested. Company funds can be taken to be used as company operations as desired by financial managers. In various companies the amount of company funds becomes liquid funds so that the portion to be invested is only a small portion (Nektarios, 2010). This can be found in other financial institutions such as bank or other non-bank financial institutions.

The results of this study can also be justified because company funds are included in the long-term funds and the presence of company funds is often used by corporate finance managers to encourage company growth when experiencing slowing growth or decreasing corporate growth. So that company funds are not always included in the same portion of investment returns. This is what affects the output of the study with insignificant results. This result is in line with the findings (Najjar et al, 2011) that profitability and revenue growth are not statistically significant.

\section{Impact of Investment Result to Company Growth}

A financial manager is always required to raise funds that are more economical according to the balance of capital structure. Companies in measuring resource management and investment efficiency are the stages of production of insurance companies that are highly considered (Tone et al, 2018). Increased capital (sources of funds) is needed in order to grow the company because it can help increase the investment channeled with the hope of getting maximum investment returns. Investment decisions that are mature and in accordance with sharia principles must be made by financial managers in order to reduce risk and increase optimal income (Sabah et al, 2019). Investment return is one of the objectives of the company and this has become the obligation of a financial manager so that the company can still generate maximum profits. In a service company or like an insurance financial institution they grow with the profit earned. so the company only hopes with the profit of the funds invested (Khan, 2014).

A growing company is impossible without investment returns. Stable investment results will encourage company growth for the better. In this study 
investment returns have a positive effect on the sustainability of the company. In accordance to the research of (Khan, 2014) Life insurance companies that rely heavily on the results of the investment channeled. To understand further, you can see the flow chart of Islamic life insurance companies in figure 2.

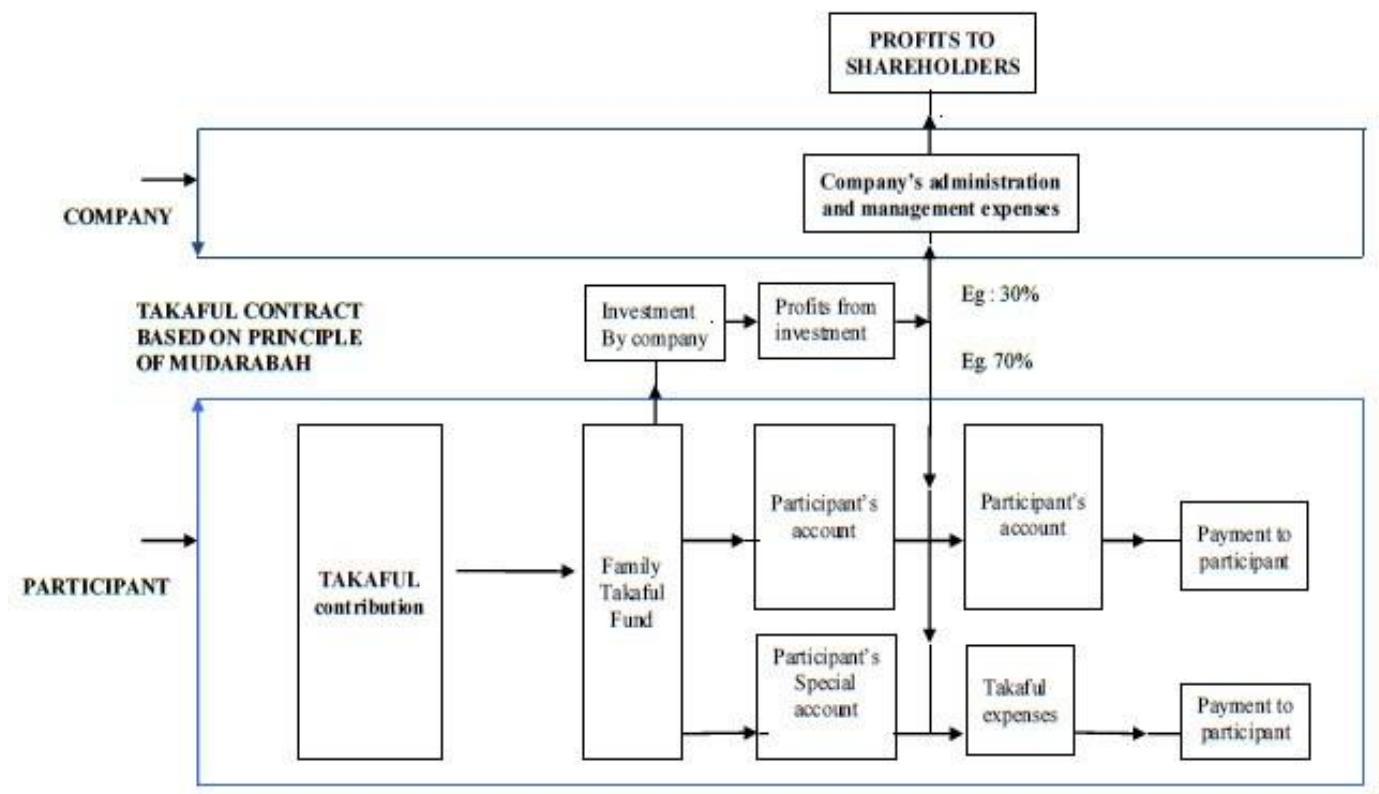

Figure 2. Islamic Insurance Operational Flow (Yusof et al, 2011)

It can be seen in the distribution of investment returns in figure 2 that the company gets a portion of $40 \%$ of the investment returns that are owned by the company. So the company grows with $40 \%$ of the investment return for the company's sustainability. This is evidence of field facts that investment returns greatly affect the company's growth. Other empirical facts show that insurance companies have a means of raising funds (products) or sources of funds allocated in the form of investments Can be seen in the distribution of investment returns in figure 2 . The company gets a portion of $40 \%$ of the investment returns that are owned by the company. So the company grows with $40 \%$ of the investment return for the company's sustainability. This is evidence of field facts that investment returns greatly affect the company's growth. Other empirical facts show that insurance companies have a means of collecting funds (products) or sources of funds allocated in the type of investment (Frenz et al, 2010). The results in this study are in line with research that investment returns can affect growth (Muthmainah, 2016)

\section{CONCLUSION}

Based on the results of the multiple linear regression tests and the Sobel test, it can be concluded that the investment results can mediate participant funds in influencing the growth of Islamic life insurance companies. Meanwhile, investment returns cannot mediate the influence of company funds in influencing the growth of Islamic life insurance companies. 
Islamic life insurance is expected to implement a better strategy in maintaining investment to remain qualified with the aim of producing maximum investment returns. Insurance companies have two main sources of income, premiums from underwriting activities, and return on investment. Insurance companies invest premiums to make a profit. Furthermore, insurance companies must use premiums wisely and balance the desire to obtain higher returns through risky investments. However, they have to maintain their liquidity to cover liabilities related to claims made when the contract is held. If they fail to balance this, they will not be able to fulfill their obligations and will go bankrupt. Prudence, sources of capital and investment returns are important components in increasing the growth of insurance companies.

\section{REFERENCES}

Akhter, W., Pappas, V., and Khan, S. U. (2017). A comparison of Islamic and conventional insurance demand: Worldwide evidence during the Global Financial Crisis. Research in International Business and Finance. https://doi.org/dx.doi.org/10.1016/j.ribaf.2017.07.079

Almajali, A.Y., Alamro, S.A., and Al-Soub, Y. . (2012). Factors Affecting the Financial Performance of Jordanian Insurance Companies Listed at Amman Stock Exchange. Journal of Management Research, 4(2). https://doi.org/doi.org/10.5296/jmr.v4i2.1482

Alshammari, AA., bin Syed Jaafar Alhabshi SM, and Saiti, B. (2018). The impact of competition on cost efficiency of insurance and takaful sectors: evidence from GCC markets based on the Stochastic Frontier Analysis. Research in International Business and Finance. https://doi.org/doi.org/10.1016/j.ribaf.2018.09.003

Baron, R. M., and Kenny, D. A. (1986). No Title. The Moderator-Mediator Variable Distinction in Social Psychological Research: Conceptual, Strategic and Statistical Considerations, 1173-1182. https://doi.org/doi.org/10.1037/0022-3514.51.6.1173

Bolin, J. H. (2014). Introduction to Mediation, Moderation, and Conditional Process Analysis: A Regression-Based Approach. Journal of Educational Measurement. https://doi.org/doi:10.1111/jedm.12050

Frazier, P. A., Tix, A. P., and Barron, K. E. (2004). Testing moderator and mediator effects in counseling psychology research. Journal of Counseling Psychology, 115-134. https://doi.org/doi.org/10.1037/0022-0167.51.1.115

Frenz, T., and Y. S. (2010). Takaful and Retakaful: Principles and Practices. Munich Re Retakaful. ISBN : 9789834377793

Hanif, M and Iqbal, A. (2014). An Evaluation of Takaful Insurance: Case of Pakistan. Journal of Islamic Economics, Banking and Finance, 13(1). https://doi.org/dx.doi.org/10.2139/ssrn.2386497

Hassan, L.F.A., Jusoh, W.J., and Hamid, Z. (2014). Determinant of Customer Loyalty in Malaysian Takaful Industry. Procedia - Social and Behavioral Sciences, $\quad 130$ 362-370. https://doi.org/doi.org/10.1016/j.sbspro.2014.04.043. 
James, L. R., and Brett, J. M. (1984). Mediators, moderators and tests for mediation. Journal of Applied Psychology, 307-321. https://doi.org/doi.org/10.1037/0021-9010.69.2.307

Judd, C. M., and Kenny, D. A. (1981). Process analysis: Estimating mediation in treatment evaluations. Evaluation Review, 602-619. https://doi.org/doi.org/10.1177/0193841X8100500502

Khan, H. (2014). Optimal Incentives for Takaful (Islamic Insurance) Operators. Journal of Economic Behavior and Organization. https://doi.org/. dx.doi.org/10.1016/j.jebo.2014.11.001

Mao, H., Carson, J.M., Ostaszewski, K.M., Wen, Z. (2013). Optimal decision on dynamic insurance price and investment portfolio of an insurer. Insurance: Mathematics and Economics. https://doi.org/doi:10.1016/j.insmatheco.2013.01.007

Muthmainah, M. (2016). The Growth of Sharia Insurance in Indonesia 2015 - 2016: an Academic Forecast Analysis. Shirkah: Journal of Economics and Business,. https://doi.org/doi.org/10.22515/shirkah.v1i1.2

Muye, I.M., and H. A. F. (2015). Does Islamic Insurance Development Promote Economic Growth? A Panel Data Analysis. Procedia Economics and Finance. https://doi.org/doi: 10.1016/S2212-5671(16)00045-9

Najjar, Naser, and Petrov, K. (2011). Capital Structure of Insurance Companies in Bahrain. International Journal of Business and Management, 6(11). https://doi.org/doi:10.5539/ijbm.v6n11p138

Nasution, Z., Adiba, E.M., and Abdulrahim, M. O. (2019). Comparison analysis of risk-based capital (RBC) performance and its effect on islamic insurance profitability in indonesia and malaysia. Al-Uqud: Journal of Islamic Economics. https://doi.org/doi: 10.26740/al-uqud.v3n2.p149-160

Nektarios, M. (2010). A Growth Theory For The Insurance Industry. Risk Management and Insurance Review,. https://doi.org/doi.10.1111/j.1540$\underline{6296.2009 .01172 . x}$

Nurbaya, S., and Alam, A. (2019). Analysis of Factors Affecting Islamic Insurance Profitability (Case Study Of Sinar Mas Islamic Insurance Period 2011-2017). Journal of Islamic Economic Laws. https://doi.org/https://doi.org/10.23917/jisel.v2i2.8595

Preacher, K. J., and Hayes, A. F. (2004). SPSS and SAS procedures for estimating indirect effects in simple mediation models. Behavior Research Methods, Instruments, and Computers. https://doi.org/doi.org/10.3758/BF03206553

Preacher, K. J., and Hayes, A. F. (2008). Asymptotic and resampling strategies for assessing and comparing indirect effects in multiple mediator models. Behavior Research Methods. https://doi.org/doi.org/10.3758/BRM.40.3.879

Puspitasari, N. (2015). Hybrid Contract And Funds Efficiency Management Of Islamic General Insurance Company (Study In Indonesia). Procedia - Social and Behavioral Sciences. https://doi.org/doi: 10.1016/j.sbspro.2015.11.033

Sabah, Nasim., and Hassan, M. K. (2019). Pricing of Islamic deposit insurance. Economics Letters. https://doi.org/doi.org/10.1016/j.econlet.2019.01.013 
114 Al-Uqud: Journal of Islamic Economics

Volume 4 Issue 1, January 2020

Tone, K., Kweh, Q. L., Lu, W.-M., and Ting, I. W. K. (2018). Modeling Investments in the Dynamic Network Performance of Insurance Companies. Omega. https://doi.org/doi.org/10.1016/j.omega.2018.09.005

Yusof, M.F., Ismail, W.Z., and Naaim, A. K. (2011). Fundamentals of Takaful. Kuala Lumpur: IBFIM. 